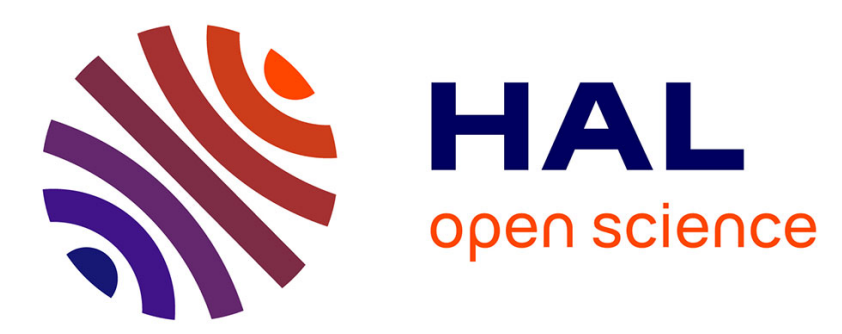

\title{
Influence of marine phytoplankton, transition metals and sunlight on the species distribution of chromium in surface seawater
}

Shun-Xing Li, Feng-Ying Zheng, Hua-Sheng Hong, Nan-Sheng Deng, Lu-Xiu Lin

\section{To cite this version:}

Shun-Xing Li, Feng-Ying Zheng, Hua-Sheng Hong, Nan-Sheng Deng, Lu-Xiu Lin. Influence of marine phytoplankton, transition metals and sunlight on the species distribution of chromium in surface seawater. Marine Environmental Research, 2009, 67 (4-5), pp.199. 10.1016/j.marenvres.2009.02.001 . hal-00563070

\section{HAL Id: hal-00563070 \\ https://hal.science/hal-00563070}

Submitted on 4 Feb 2011

HAL is a multi-disciplinary open access archive for the deposit and dissemination of scientific research documents, whether they are published or not. The documents may come from teaching and research institutions in France or abroad, or from public or private research centers.
L'archive ouverte pluridisciplinaire HAL, est destinée au dépôt et à la diffusion de documents scientifiques de niveau recherche, publiés ou non, émanant des établissements d'enseignement et de recherche français ou étrangers, des laboratoires publics ou privés. 


\section{Accepted Manuscript}

Influence of marine phytoplankton, transition metals and sunlight on the species distribution of chromium in surface seawater

Shun-Xing Li, Feng-Ying Zheng, Hua-Sheng Hong, Nan-sheng Deng, Lu-Xiu

Lin

PII:

S0141-1136(09)00024-5

DOI:

10.1016/j.marenvres.2009.02.001

Reference:

MERE 3317

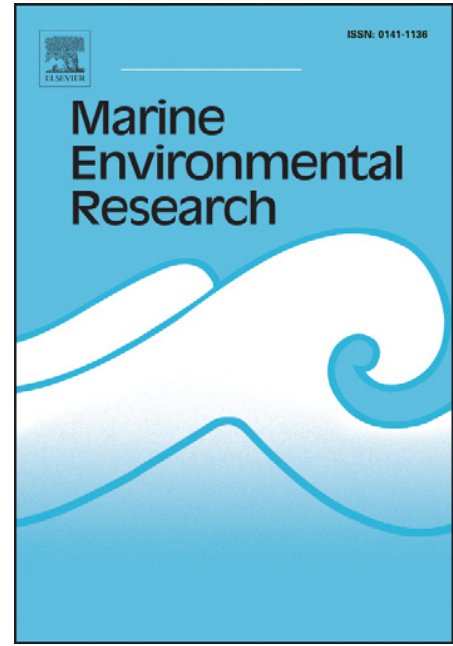

To appear in:

Marine Environmental Research

Received Date:

15 June 2007

Revised Date:

3 January 2009

Accepted Date:

20 February 2009

Please cite this article as: Li, S-X., Zheng, F-Y., Hong, H-S., Deng, N-s., Lin, L-X., Influence of marine phytoplankton, transition metals and sunlight on the species distribution of chromium in surface seawater, Marine Environmental Research (2009), doi: 10.1016/j.marenvres.2009.02.001

This is a PDF file of an unedited manuscript that has been accepted for publication. As a service to our customers we are providing this early version of the manuscript. The manuscript will undergo copyediting, typesetting, and review of the resulting proof before it is published in its final form. Please note that during the production process errors may be discovered which could affect the content, and all legal disclaimers that apply to the journal pertain. 


\section{Influence of marine phytoplankton, transition metals and sunlight on the 2 species distribution of chromium in surface seawater}

3 Running head: Photo-induced reduction of $\mathrm{Cr}(\mathrm{VI})$ in sunlit seawater

4 Shun-Xing Li ${ }^{1 *}, 2$ Feng-Ying Zheng ${ }^{1,3}$, Hua-Sheng Hong ${ }^{2}$, Nan-sheng Deng ${ }^{3}$, Lu-Xiu Lin ${ }^{1}$

$5{ }^{1}$ Department of Chemistry \& Environmental Science, Zhangzhou Teachers College, Zhangzhou, 363000, China

$6 \quad{ }^{2}$ State key Lab for Marine Environmental Science, Xiamen University; Xiamen, 361005, China

$7 \quad{ }^{3}$ Department of Environment Science, Wuhan University, Wuhan, 430072, China

8 Corresponding author:

Prof. Dr. Li Shun-xing

Postal address: Department of Chemistry and Environmental Science, Zhangzhou Teachers College, Zhangzhou,

Fujian, 363000, P.R.China

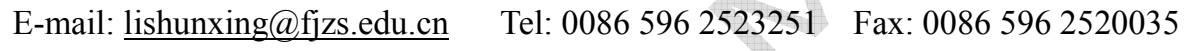


9

10

\section{Abstract}

The photo-reduction of $\mathrm{Cr}(\mathrm{VI})$ to $\mathrm{Cr}(\mathrm{III})$ by marine phytoplankton (diatoms, red and green algae), with or without the presence of transition metals (Fe(III), $\mathrm{Cu}(\mathrm{II})$ and $\mathrm{Mn}(\mathrm{II}))$ was studied. The direct influence of marine phytoplankton on the photochemical reduction of $\mathrm{Cr}(\mathrm{VI})$ was confirmed for the first time, and two kinds of mechanism were suggested to be responsible for the species transformation: (a) $\mathrm{Cr}(\mathrm{VI})$ in excited state could be reduced by the electron donor in its ground state via photo produced electrons; and (b) the solvated electrons reduce the $\mathrm{CrO}^{2-}$ anions in their ground state. The conversion ratio of $\mathrm{Cr}(\mathrm{VI})$ to $\mathrm{Cr}$ (III) increased with increasing algae concentration and irradiation time. Different species of marine phytoplankton were found to have different photo-reducing abilities. The photochemical redox of transition metals could induce the species transformation of chromium. After photo-reduction by marine phytoplankton and transition metals, the ratio of $\mathrm{Cr}(\mathrm{VI})$ to $\mathrm{Cr}(\mathrm{III})$ was in the range of $1.45 \sim 2.16$ for five green algae (Tetraselmis levis, Chlorella autotrophica, Dunaliella salina, Nannochloropsis sp., and Tetraselmis subcordiformis), and only 0.48 for Phaeodactylum tricornutum (diatom) and 0.71 for Porphyridium purpureum (red alga). The species distribution of chromium in the sunlit surface seawater was greatly affected by combined effects of marine phytoplankton (main contributor) and transition metals; both synergistic and antagonistic effects were observed. The results provided further insights into the species distribution and the biogeochemical cycle of chromium, and have significant implications for the risk assessment of chromium in the sunlit surface seawater.

Keywords: Chromium, Photoreduction, Marine phytoplankton, Species transformation 


\section{Introduction}

Developing a full understanding of the distribution and biogeochemical behavior of trace elements in seawater has the potential to provide: (a) unique insights into a wide range of oceanic processes and (b) the mechanisms controlling the fate of contaminants added to the ocean by human activities. Both the Joint Global Ocean Flux Study (JGOFS) and the Land-Ocean Interactions in the Coastal Zone Project (LOICZ), the core projects of the International Geosphere-Biosphere Program (IGBP), are focused on the distribution, transport, transform, cycle, end-result, production and consumption of trace metals.

In seawater, chromium exists in two different oxidation states, $\mathrm{Cr}(\mathrm{VI})$ and $\mathrm{Cr}(\mathrm{III})$. Similar to many other elements, the toxicological and physiological behavior of chromium depends on its oxidation state, binding partners, potential ligands and solubility. Chromium(III) shows a high affinity for particles at neutral pH (7-8), and is a micronutrient for higher mammals (Mertz, 1993). In contrast, $\mathrm{Cr}(\mathrm{VI})$ is toxic and mobile, and can be easily absorbed by living organisms (Richard and Bourg, 1991; Standeven and Wetterhahn, 1991). Chromium(VI) is an important industrial metal that is considered a priority pollutant by many countries including the USA, UK and Canada. Reduction of $\mathrm{Cr}(\mathrm{VI})$ to $\mathrm{Cr}(\mathrm{III})$ will not only reduce the toxicity of chromium to living organisms, but also help to precipitate chromium out at $\mathrm{pH} 8.1$ (mainly as insoluble $\mathrm{Cr}(\mathrm{OH})_{3}$ and soluble coordination compounds). The species transformation of chromium would thus greatly affect its toxicity or bioavailability and its biogeochemical cycle in the ocean.

Thermodynamic calculations predict that in oxygenated seawater $(\mathrm{pH} 8.1$ and $\mathrm{pE} 12.5)$ the ratio of $\mathrm{Cr}(\mathrm{VI})$ to $\mathrm{Cr}$ (III) is $10^{21}$ (Elderfield, 1970), i.e., chromium should exist almost exclusively as $\mathrm{Cr}(\mathrm{VI})$, but thermodynamically unstable $\mathrm{Cr}(\mathrm{III})$ has also been detected, the ratio of $\mathrm{Cr}(\mathrm{VI})$ to $\mathrm{Cr}(\mathrm{III})$ was in the range of 1.6 3.1 (Hirata et al., 2000). It is important to provide valid explanations for the distribution of $\mathrm{Cr}$ (VI)/Cr (III) in order to understand the species transformation and biogeochemical behavior of chromium, and to assess its toxicity in seawater. The mechanistic investigations on the reduction of chromium have caused much attention 
51

(Kieber and Helz, 1992; Buerge and Hug, 1997; Hug et al., 1997; Abu-Saba et al., 2000). Until now, the studies of species transformation of chromium, especially the mechanism of reduction, were focused on single environmental factor such as marine bacteria (Smillie et al., 1981; Yang et al., 1994), hydrogen peroxide (Pettine and Millero,1990; Pettine et al., 1991), iron (Deng et al., 1996; Buerge and Hug, 1997; Hug et al., 1997) and copper (Abu-Saba et al., 2000), which could not provide conclusive reasons for the species transformation and the distribution of chromium in the sunlit surface seawater.

The kinetic effects of biological uptake (Roitz et al., 2002; Li et al., 2007), redox and photochemical reaction from biological activity on the species transformation and biogeochemical cycle of trace elements in natural waters were very important, in fact may dominate (Costa and Liss, 2000; Powell and Wilson-Finelli, 2003; Rose and Waite, 2003). As the effects on the formation and decay of hydrogen peroxide and hydroxyl radicals by some green and blue algae in freshwater were detected (Zepp and Schlotzhauer, 1983; Zuo and Hoigné, 1992; Zuo and Hoigné, 1993; Liu et al., 2004; Wu et al., 2004), the species transformation of trace elements might be affected by photochemical behavior that is driven by marine phytoplankton. In our previous study, the photo-oxidation of $\mathrm{Sb}(\mathrm{III})$ in seawater was observed for the first time and could be accelerated by marine phytoplankton (Li et al., 2006a). Dissolved organic matter (DOM) derived from phytoplankton could facilitate $\mathrm{Cr}$ reduction in the presence of light (Sanders and Riedel, 1987). A field experiment implies that $\mathrm{Cr}(\mathrm{III})$ concentrations were greatest during periods of high biological activity, as indicated by strong correlations between the ratio of $\mathrm{Cr}(\mathrm{III}): \mathrm{Cr}(\mathrm{VI})$ and primary productivity (Connelly et al., 2006). Both the influence of marine phytoplankton itself (excluding its exudates such as DOM) on the photo-reduction of trace metals and the information on species specific differences in how different phytoplankton might facilitate this reaction have not yet been published.

Transition metals in seawater, including iron, manganese and copper, are usually complexed with organic ligands, forming coordinated complexes (Deng et al., 1997; Powell and Wilson-Finelli, 2003). Since the 
electrons in these coordinated metal complexes and their organic ligands are easy to transport, they could readily absorb ultraviolet and visible light and have remarkable photochemical activities. Reaction could affect the redox potential of seawater in the euphotic layer and the speciation of trace elements (Zhang, 2000; Zhang and Yang, 2000). For example, photo-induced reduction of Fe(III)-multi-hydroxyl-acid complex and Fe(III)-hydroxy complexes was the significant source of Fe(II), active oxygen species and hydroxyl radicals (Deng et al., 1997; Zhang et al, 2001; White et al., 2003). In sunlit oxygenated seawater, the dissolved manganese present can be found in the reduced Mn (II) form. (Zhang and Yang, 2000). The photo-reduction of Cr(VI) could be similarly driven by photo-redox from transition metals with light, e.g., the photocatalytic cycle of iron contributed to reduction of $\mathrm{Cr}(\mathrm{VI})$ (Kocot et al., 2007). The non-living substances in seawater facilitate the photoreduction of $\mathrm{Cr}(\mathrm{VI})$, including inorganic substances such as iron(II) (Buerge and Hug, 1997; Zhang et al., 1995), $\mathrm{Cu}(\mathrm{I})$ (Millero, 1989), hydrogen sulfide (Pettine et al., 1994), superoxide $\left(\mathrm{O}_{2}^{-}\right)$(Abu-Saba et al., 2000), and organic compounds such as oxalate and citrate (Hug et al., 1997). The presence of Mn(II) affects the oxidation of $\mathrm{Cr}(\mathrm{III})$ (Zhang, 2000), but the presence of manganese on the influence of photoreduction of $\mathrm{Cr}(\mathrm{VI})$ in seawater is still not understood. Furthermore, multifactor mechanisms of photo-induced species transformation of chromium have not been discussed to date.

The key parameters affecting the species transformation of trace elements in sunlit surface seawater should include sunlight, marine phytoplankton due to their bioactivity and photo-reactivity and non-living substances such as transition metals due to photochemical activity. Here we report our study on the photo-induced reduction of $\mathrm{Cr}(\mathrm{VI})$ in the presence of marine phytoplankton with light, transition metals with light, and the combination of both. Our objectives were to (a) study the influence of marine phytoplankton itself and Mn(II) on the photochemical reduction of $\mathrm{Cr}(\mathrm{VI})$ for the first time; (b) exploit the combined effects from the coexistence of bi- and tri- valent transition metals or the co-presence of marine phytoplankton and transition metals on the photochemical reduction; (c) provide mechanistic explanations for the distribution of $\mathrm{Cr}(\mathrm{VI})$ and 
$\mathrm{Cr}(\mathrm{III})$; (d) offer new insights into chromium biogeochemical behavior; and (e) assist in risk or bioavailability assessment of $\mathrm{Cr}(\mathrm{VI}) / \mathrm{Cr}(\mathrm{III})$ in the sunlit surface seawater.

\section{Materials and methods}

\subsection{Apparatus}

A Model GBC 932AA atomic absorption spectrometer (GBC Co., Australia) with a chromium hollow-cathode lamp operated at $6.0 \mathrm{~mA}$ was used for all the determinations of chromium. A slit of $1.3 \mathrm{~nm}$ was selected in order to isolate $357.9 \mathrm{~nm}$ chromium absorption line. A UV-1200 PC spectrophotometer (Pekin Ruili Co., China) was used for the determination of the optical density of algal suspensions. The irradiation experiments were performed with a high-pressure mercury lamp (125 W, its photoemission spectrum was illustrated in Fig. 1) that was covered by glass tube as a filter in order to keep the wavelength of the transmitted light over $300 \mathrm{~nm}$. The illuminating intensity was $10000 \mu \mathrm{mol} \cdot \mathrm{photons} \cdot \mathrm{m}^{-2} \cdot \mathrm{s}^{-1}$, which was detected with a Digit Lux meter (TES 1332, Taiwan, China).

\subsection{Reagents}

All other chemicals were of analytical grade from Shanghai Experiment Reagent Co., China. Double de-ionized water of $18 \mathrm{M} \mathrm{ohms} \mathrm{cm}^{-1}$ specific resistivity, obtained in a Milli-Q plus Millipore system, was used to prepare all the solutions and to rinse the previously cleaned laboratory material. Standard stock solutions of $\mathrm{Cr}(\mathrm{III})$ and $\mathrm{Cr}(\mathrm{VI})$ were prepared, respectively, by dissolving an appropriate amount of $\mathrm{CrCl}_{3}$ and $\mathrm{K}_{2} \mathrm{Cr}_{2} \mathrm{O}_{7}$

(Merk Co.) in $0.5 \mathrm{~mol} \mathrm{~L}^{-1} \mathrm{HCl}$ solution. All stock solutions were stored in the dark at $4{ }^{\circ} \mathrm{C}$. Working standard solutions of lower concentrations were prepared daily by appropriate dilution. In order to avoid the adsorption of chromium and contamination, Teflon vessels and $0.45 \mu \mathrm{m}$ Nuclepore membrane filter (Teflon) were used, which were precleaned in concentrated hydrochloric acid for $24 \mathrm{~h}$. All solutions were sterilized in an autoclave for $20 \mathrm{~min}$ at $121^{\circ} \mathrm{C}$ and $2 \mathrm{bar}$, and prepared in a dark chamber. 


\subsection{Marine phytoplankton cultures}

Seven species of marine phytoplankton, including the diatom Phaeodactylum tricornutum (A), red alga Porphyridium purpureum (B), and the green algae Tetraselmis levi (C), Chlorella autotrophic (D), Dunaliella salina (E), Nannochloropsis sp. (F), and Tetraselmis subcordiformis (G), were obtained from the Microbial Culture Laboratory, Ocean University of Qingdao, China. Marine phytoplankton were cultivated in f/2 media prepared with sterile-filtered (Whatman GF/F glass fiber filter) artificial seawater prepared with the formula of Keller ( $\mathrm{pH}$ 8.1), with a cultivation temperature of $18 \pm 0.5^{\circ} \mathrm{C}$, and at a photon flux density of 140 $\mu \mathrm{mol} \cdot$ photons. $\mathrm{m}^{-2} \cdot \mathrm{s}^{-1}$ with a day-night cycle of $12: 12 \mathrm{~h}$.

\subsection{Determination of the biomass}

The size of different microalgal genera was different. If the cells were from the same algal specie and cultivated at the same time, the dry weight of the cells was linearly correlated with the optical density of the alga suspension (Schmitt et al., 2001; Wang et al., 1997). The dry weight of the biomass was determined gravimetrically at several optical densities of $500 \mathrm{ml}$ alga suspension after being dried at $105^{\circ} \mathrm{C}$ for $24 \mathrm{~h}$. The optical density was determined with a UV-Vis spectrophotometer at specific wavelengths for A $(750 \mathrm{~nm}), \mathrm{B}$ (750 nm), C (545 nm), D (486 nm), E (545 nm), F (475 nm), G (443 nm). Calibration of the dry weight of the biomass against the optical density was carried out respectively. With the help of these calibrations, a fast determination of marine phytoplankton concentration was feasible.

\subsection{Verification of the bioactivity}

Because the chromium concentration in ocean water is in a range of 0.2 to $50 \mu \mathrm{g} \mathrm{L}^{-1}$ (U.S.EPA, 2006) and the content of total chromium in coastal seawater was found to be $4 \mu \mathrm{g} \mathrm{L} \mathrm{L}^{-1}$ (Nicolai et al., 1999), the initial concentration of chromium in artifical seawater was $5 \mu \mathrm{g} \mathrm{L} \mathrm{L}^{-1}$ in the irradiation experiments and dark controls throughout this study. Tests were carried out to ensure that marine phytoplankton could survive and keep normal 
141

142

143

144

bioactivity under the experimental conditions. Marine phytoplankton with concentrations ranging from 5 to 20 ng $\mathrm{ml}^{-1}$ were transferred to artificial seawater containing $5 \mu \mathrm{g} \mathrm{L}^{-1} \mathrm{Cr}(\mathrm{VI})$ or $\mathrm{Cr}(\mathrm{III})$ and kept $24 \mathrm{~h}$ under irradiation. The cells from the filters were resuspended into fresh medium under normal growth conditions. The specific growth rates over the next 5 days and the cell shapes were recorded in triplicate cultures, and compared with the normal growth rates and cell shapes. Abnormal phenomena were not observed, so it could be concluded that $5 \mu \mathrm{g} \mathrm{L}^{-1}$ of $\mathrm{Cr}(\mathrm{VI})$ and $\mathrm{Cr}(\mathrm{III})$ were not toxic to the marine phytoplankton, i.e. living algal cells were used in our photochemical experiments.

\subsection{Determination of $C r(V I)$ and $C r(I I I)$}

Speciation analysis of chromium was performed following the procedures of $\mathrm{Zhu}$ and $\mathrm{Li}$ (2001). The detection limit $(3 \sigma, \mathrm{n}=11)$ was $0.03 \mu \mathrm{g} \mathrm{L} \mathrm{L}^{-1}$ for $\mathrm{Cr}(\mathrm{VI})$ and $0.01 \mu \mathrm{g} \mathrm{L}{ }^{-1}$ for $\mathrm{Cr}(\mathrm{III})$, respectively, at the level of $0.1 \mu \mathrm{g} \mathrm{L}{ }^{-1}$, the precision (relative stand deviation ) was $3.3 \%$ for $\mathrm{Cr}(\mathrm{VI})$ and $2.8 \%$ for $\mathrm{Cr}(\mathrm{III})$, respectively. For samples spiked with both $\mathrm{Cr}(\mathrm{III})$ and $\mathrm{Cr}(\mathrm{VI})$, the recovery varied from 97 to $102 \%$ for $\mathrm{Cr}(\mathrm{III})$ and from 96 to $103 \%$ for $\mathrm{Cr}(\mathrm{VI})$.

To study the accuracy of this method, a synthetic artificial seawater sample with $0.1 \mu \mathrm{g} \mathrm{L}{ }^{-1} \mathrm{Cr}(\mathrm{VI}), 0.1 \mu \mathrm{g}$ $\mathrm{L}^{-1} \mathrm{Cr}(\mathrm{III})$, and interfering substances (55 $\mathrm{ng} \mathrm{L}^{-1} \mathrm{Fe}(\mathrm{III}), 250 \mathrm{ng} \mathrm{L}^{-1} \mathrm{Cu}(\mathrm{II}), 14 \mathrm{ng} \mathrm{L}^{-1} \mathrm{Mn}(\mathrm{II})$, the exudates of 20 $\mathrm{ng} \mathrm{m} \mathrm{m}^{-1}$ marine phytoplankton), was analyzed. The concentration measured in synthetic water sample was $0.10 \pm 0.01 \mu \mathrm{g} \mathrm{L}^{-1}$ for $\mathrm{Cr}(\mathrm{III}), 0.10 \pm 0.01 \mu \mathrm{g} \mathrm{L}{ }^{-1}$ for $\mathrm{Cr}(\mathrm{V})$. The results demonstrated that: (a) the concentrations of $\mathrm{Cr}(\mathrm{III})$ and $\mathrm{Cr}(\mathrm{VI})$ in synthetic artificial seawater sample agreed well with the added concentrations; (b) this method avoided the reduction of $\mathrm{Cr}(\mathrm{VI})$ during the preliminary concentration and analysis process; (c) no interference from the components of photochemical experimental system was observed.

Precautions were also taken to minimize the adsorption of $\mathrm{Cr}(\mathrm{III})$ and $\mathrm{Cr}(\mathrm{VI})$ during the experiments. These included: (a)Teflon flasks were employed as the reactors for their good transparence and weak adsorptive 
163

164

165

166

167

168

169

property; (b) the solutions or algal suspensions were stirred at $100 \mathrm{rpm}$ during the irradiation experiments and dark controls to simulate the current of seawater; (c) marine phytoplankton which have reached adsorption equilibrium with $5 \mu \mathrm{g} \mathrm{L}^{-1} \mathrm{Cr}(\mathrm{VI})$ in artificial seawater were used to reduce the adsorption from marine phytoplankton in photochemical experiments; our preliminary study showed that the adsorption behaviors of $\mathrm{Cr}(\mathrm{VI})$ and $\mathrm{Cr}(\mathrm{III})$ by marine phytoplankton were similar; (d) A relatively larger volume (500 ml) solution or marine phytoplankton suspension was used to enhance the absolute mass of $\mathrm{Cr}(\mathrm{VI})$ in it, to weaken the relative effects from the adsorptions.

Accumulation of anionic $\mathrm{Cr}(\mathrm{VI})$ (as chromate) in marine phytoplankton is generally slow (Wang, et al., 2001). The preliminary study showed that the total concentration of chromium in solution or filtrate of marine phytoplankton suspension could be kept at $5 \pm 0.06 \mu \mathrm{g} \mathrm{L}^{-1}$. In other words, the interferences of adsorption, the deviation of adsorptive property between $\mathrm{Cr}(\mathrm{VI})$ and $\mathrm{Cr}(\mathrm{III})$, and the algae exudates on the determination could be avoided through above-mentioned methods, and the influence from bio-absorption and biological transformation on the distribution of chromium could be ignored.

\subsection{Photochemical experiments}

The cultures in the $\log$ phase were chosen to start photochemical experiments. Prior to the illumination experiment, the procedure described by Tovar-Sanchez et al.(2003) was used to remove trace metals that might have adsorbed on the algae cells, and it was harmless to live alga cells, and used in experiments. This procedure involved washing the cells by gentle agitation with trace metal clean reagent (Tovar-Sanchez et al., 2003) for 5 min, filtering with $0.45 \mu \mathrm{m}$ membrane filter. The filters were rinsed three times with $5 \mathrm{ml}$ of artificial seawater. Photo-induced reduction of $5 \mu \mathrm{g} \mathrm{L}^{-1} \mathrm{Cr}(\mathrm{VI})$ in $500 \mathrm{ml}$ artificial seawater $\left(\mathrm{pH} 8.1,18 \pm 0.5{ }^{\circ} \mathrm{C}\right)$ in the presence of marine phytoplankton, transition metals, and the combination of both was studied. The vessel temperature was controlled as $18 \pm 0.5^{\circ} \mathrm{C}$. Because phytoplankton densities in subsurface water and at $20 \mathrm{~m}$ depth were $870.9 \times 10^{3} \mathrm{~L}^{-1}$ and $327.8 \times 10^{3} \mathrm{~L}^{-1}$, respectively (Tengku-Rozaina and Ibrahim, 2001), the 
186

concentration of marine phytoplankton was $5,8,10,15,20 \mathrm{ng} \mathrm{ml}^{-1}$ for marine phytoplankton-light system and $10 \mathrm{ng} \mathrm{ml}^{-1}$ for marine phytoplankton-transition metals-light system respectively. The concentration of transition metals was $55 \mathrm{ng} \mathrm{L}^{-1}$ for $\mathrm{Fe}(\mathrm{III}), 250 \mathrm{ng} \mathrm{L}^{-1}$ for $\mathrm{Cu}(\mathrm{II})$, and $14 \mathrm{ng} \mathrm{L}^{-1}$ for $\mathrm{Mn}$ (II), i.e., the average concentration of trace elements in actual seawater (Feng et al., 1999). The suspension or solution was agitated in an orbital shaker at $100 \mathrm{rpm}$. The suspension or solution was sampled $50 \mathrm{ml}$ after irradiation for $0.5,1,1.5,2,3,4,5,6,7$, and $8 \mathrm{~h}$.

These samples were filtered with $0.45 \mu \mathrm{m}$ membrane filter and the concentration of $\mathrm{Cr}(\mathrm{VI})$ and $\mathrm{Cr}(\mathrm{III})$ in the filtrates was determined respectively by FI-HG-AAS. The suspension or solution was covered with aluminum foil and kept in the dark before and after irradiation. Dark controls were carried out in parallel. The conversion percent was the concentration ratio between $\mathrm{Cr}(\mathrm{III})$ and total chromium at steady state.

\section{Results and discussion}

\subsection{Effect of marine phytoplankton on the reduction of $\mathrm{Cr}$ (VI)}

Light irradiation of $5 \mu \mathrm{g} \mathrm{L}{ }^{-1} \mathrm{Cr}(\mathrm{VI})$ in artificial seawater with marine phytoplankton resulted in the formation of $\mathrm{Cr}(\mathrm{III})$, but $\mathrm{Cr}(\mathrm{III})$ could not be detected in the dark control experiments. Its conversion ratio under different species and concentrations of marine phytoplankton and different irradiation times was shown in Fig. 2. The redox equilibrium between $\mathrm{Cr}$ (VI) and $\mathrm{Cr}$ (III) was also observed from Fig. 2.

Light irradiation was essential to drive the reduction of $\mathrm{Cr}(\mathrm{VI})$ by marine phytoplankton, because $\mathrm{Cr}(\mathrm{VI})$ is thermodynamically stable in the presence of oxygen, its reduction in aerobic environment is an endergonic process, requiring investment of energy from an external source. To our knowledge, this was the first time that marine phytoplankton itself could achieve the photoreduction of $\mathrm{Cr}(\mathrm{VI})$ was confirmed, because that: (a) although DOM derived from phytoplankton has been proved to facilitate $\mathrm{Cr}$ reduction in the presence of light, DOM is just the exudate from marine phytoplankton, not marine phytoplankton itself; (b) prior to our 
photochemical experiments, the marine phytoplankton were rinsed three times with $5 \mathrm{ml}$ of artificial seawater to remove exudates such as DOM; and (c) after light irradiation $30 \mathrm{~min}, \mathrm{Cr}$ (III) could be detected, at the same time, the concentration of total organic carbon in seawater at this time is less than the detection limit of $4 \mu \mathrm{g} \mathrm{L}^{-1}$ detected with to use a TOC-Vcph (Shimadzu Co.) analyzer.

In alkaline oxygenated solutions such as sunlit surface seawater, the $\mathrm{CrO}_{4}{ }^{2-}$ anions are predominant (Mytych et al., 2004). Two kinds of mechanism were suggested to be responsible for the transformation of $\mathrm{Cr}(\mathrm{VI})$ to $\mathrm{Cr}(\mathrm{III})$ : (a) $\mathrm{Cr}(\mathrm{VI})$ in excited state could be reduced by the electron donor in its ground state via photoinduced electron transfer; and (b) solvated electrons reduce the $\mathrm{CrO}_{4}{ }^{2-}$ anions in their ground state by means of thermal reduction. The above mechanisms were based on: (a) the photoreduction of $\mathrm{CrO}_{4}{ }^{2-}$ mediated by the electron donor (e.g. phenol and 2,3-butanediol) can proceed in alkaline oxygenated solutions (Mytych et al., 2003; Cieśla et al., 2004); (b) Cr(VI) could be thermal reduced by hydrated electrons photogenerated by phenol (Mytych et al., 2004); (c) the hydrated electron can be produced by the photolysis of the aromatic carboxyl acids (Calza and Pelizzetti, 2004); and (d) the surface acid groups such as phenolic hydroxyl and carboxylic acids are on the surface of marine phytoplankton cells (Garden-Torresdey et al., 1990; Wang et al., 1997; Li et al., 2006b). The possible mechanism of the influence of marine phytoplankton itself on the photochemical reduction of $\mathrm{Cr}(\mathrm{VI})$ was proposed as follows:

$\mathrm{Cr}(\mathrm{VI})+\mathrm{ROH}+\mathrm{OH}^{-}+h v \rightarrow \mathrm{Cr}(\mathrm{V})+\mathrm{RO} \cdot+\mathrm{H}_{2} \mathrm{O}$

$\mathrm{ROH}+\mathrm{OH}^{-}+h v \rightarrow \mathrm{RO} \cdot+\mathrm{e}_{\mathrm{solv}}{ }^{-} \cdot+\mathrm{H}_{2} \mathrm{O} \quad$ or $\mathrm{RCOOH}+\mathrm{OH}^{-}+h v \rightarrow \mathrm{RCOO} \cdot+\mathrm{e}_{\text {solv }}{ }^{-}+\mathrm{H}_{2} \mathrm{O}$

$\mathrm{Cr}(\mathrm{VI})+\mathrm{e}_{\mathrm{solv}}^{-} \cdot \rightarrow \mathrm{Cr}(\mathrm{V})$

$3 \mathrm{Cr}(\mathrm{V}) \rightarrow 2 \mathrm{Cr}(\mathrm{VI})+\mathrm{Cr}(\mathrm{III})$

and/or

$\mathrm{Cr}(\mathrm{V})+\mathrm{ROH} \rightarrow \mathrm{Cr}(\mathrm{III})+$ aldehyde/ketone

The concentration of the coloured dissolved organic matter (CDOM) derived from phytoplankton 
231

232

increased with increasing the light irradiation time from $0.5 \mathrm{~h}$ to $8 \mathrm{~h}$. The hydrated electron could be produced by the photolysis of CDOM, then could facilitate $\mathrm{Cr}(\mathrm{VI})$ reduction (Thomas-Smith and Blough, 2001). The photo-production of hydroxyl radical in seawater with marine phytoplankton under high-pressure mercury lamp was observed by us ( $\mathrm{Li}$ et al., 2008). The photo-production of hydroxyl radical enhances the concentration of $\mathrm{Fe}(\mathrm{II}), \mathrm{Cu}(\mathrm{I})$ and $\mathrm{Mn}(\mathrm{II})$ in the sunlit surface seawater, induced the $\mathrm{Cr}(\mathrm{VI})$ reduction. At the same time, marine phytoplankton could adsorb and complex chromium by their surface acid groups, which could change the redox potential of chromium.

Fig. 2. indicated that the conversion ratio of $\mathrm{Cr}(\mathrm{VI})$ of $\mathrm{Cr}(\mathrm{III})$ was greatly affected by the species of marine phytoplankton, its concentrations and the irradiation time. The conversion ratio increased and the oxidation-reduction equilibrium time shortened with increasing algae concentration. As the influence factors of marine phytoplankton on the photochemical reduction of $\mathrm{Cr}(\mathrm{VI})$, the surface acid amount on the surface of marine phytoplankton cells (Wang et al., 1997), the components and contents of CDOM, and the interaction between marine phytoplankton (or CDOM) and trace metals (chromium, iron, copper and manganese), were different for different species of marine phytoplankton.

\subsection{Effect of transition metals on the reduction of $\mathrm{Cr}$ (VI)}

Our experiments proved remarkable but different photochemical activity on the species transformation of chromium from transition metals ( $\mathrm{Fe}(\mathrm{III}), \mathrm{Cu}(\mathrm{II})$, and $\mathrm{Mn}(\mathrm{II}))$. $\mathrm{Cr}(\mathrm{III})$ could not be detected in the dark control experiments, so irradiation must also be essential for photochemical activity for transition metals. In seawater,

$\mathrm{Fe}(\mathrm{III}), \mathrm{Cu}(\mathrm{II})$, and $\mathrm{Mn}(\mathrm{II})$ could be chelated by organic substances such as citrate and gluconate (Zhang and Yang, 2000), and electronic transition from such coordinated transition metals complexes could be induced easily by light.

Through photo-induction, $\mathrm{Fe}(\mathrm{III})$ and $\mathrm{Cu}(\mathrm{II})$ were reduced into $\mathrm{Fe}(\mathrm{II})$ and $\mathrm{Cu}(\mathrm{I})$, and $\mathrm{Mn}$ (II) was oxidized into $\mathrm{Mn}(\mathrm{III})$ and $\mathrm{Mn}(\mathrm{IV})$ oxide $\left(\mathrm{MnO}_{\mathrm{x}}\right)$; at the same time, $\mathrm{Fe}(\mathrm{II})$ and $\mathrm{Cu}(\mathrm{I})$ were oxidized by oxidants such as 
254

255

256

257

258

259

260

261

262

263

264

265

266

267

hydroxyl and superoxide radicals, $\mathrm{H}_{2} \mathrm{O}_{2}$, and $\mathrm{MnO}_{\mathrm{x}}$ was reduced to $\mathrm{Mn}(\mathrm{II})$ by photo-activation (Zuo and Hoigné, 1992; Zuo and Hoigné, 1993; Zhang et al., 1995; Voelker and Sedlak, 1995; Zuo and Jones, 1997; Zhang and Yang, 2000; Voelker et al., 2000; Thomas-Smith and Blough, 2001; Deng et al., 2006). Photolysis of the monohydroxyl complex of $\mathrm{Fe}(\mathrm{OH})^{2+}$ and oxidation reaction between transition metals ( $\left.\mathrm{Fe}(\mathrm{II}), \mathrm{Cu}(\mathrm{I}), \mathrm{Mn}(\mathrm{II})\right)$ and oxidants $\left(\mathrm{O}_{2}, \mathrm{H}_{2} \mathrm{O}_{2}\right)$ have been proposed as major sources of $\cdot \mathrm{OH}$ and $\cdot \mathrm{O}_{2}{ }^{-}$in sunlit surface waters ( $\mathrm{Zuo}$ and Hoigné, 1992; Zuo and Hoigné, 1993; Zuo and Jones, 1997; Wang and Yang, 2004). Superoxide and its conjugate acid, hydroperoxyl radical $\left(\mathrm{HO}_{2}\right.$, Zafiriou, 1990), are produced in sunlit natural waters through photochemical reactions. The bimolecular dismutation of superoxide has been postulated as the main source of hydrogen peroxide in the open ocean (Petasne and Zika, 1987). Hydrogen peroxide is produced by photochemical reactions in surface waters and occurs at concentration levels between $10^{-6}$ and $10^{-8} \mathrm{~mol} \mathrm{~L}^{-1}$ (Sulzberger et al., 1997). The redox reaction of transition metals could induce the species transformation of chromium. For example, Fe(II) has been shown to act as the electron donor in $\mathrm{Cr}(\mathrm{VI})$ reduction (Gaberell et al., 2003) and the excited $\mathrm{Fe}(\mathrm{III})$ complexes, e.g. $[\mathrm{Fe}(\mathrm{edta}) \mathrm{OH}]^{2-}$ behave as even stronger electron donors towards Cr(VI) (Cieśla et al., 2007; Kocot et al., 2007).

The electronic shell distribution and organic ligands of iron, copper and manganese are different. The value of $\mathrm{E}^{0}$, i.e., the ability of coordinated complex to accept or donate electron is different, so the effect of different transition metals on the photo-reduction of $\mathrm{Cr}(\mathrm{VI})$ is quite different. The conversion ratio and redox equilibration time were listed in Table 1.

In the single transition metal experiments, copper showed the strongest photochemical activity and manganese the weakest. In the presence of two transition metals, the photo-oxidation activity was higher than the respective single metal. When all the three transition metals were present, the conversion ratio of chromium was higher than that of each of the single metal and two metal pair. Though all of the transition metals, including iron, copper and manganese, have photochemical activity, the co-existence of bi- or tri-valent 
elements could increase the yield of radicals. At the same time, collisional deactivation of radicals could also occur. Therefore, the co-existence of transition metals did not simply show additive property or synergistic effect on the photo-oxidation activity.

\subsection{Combined effect of marine phytoplankton and transition metals on the reduction of $\mathrm{Cr}(\mathrm{VI})$}

The photo-reduction of $\mathrm{Cr}(\mathrm{VI})$ was facilitated not only by marine phytoplankton, but also by transition metals; the combination effects of both were shown in Fig.3. It could be seen from Fig.3 that the reduction behavior of $\mathrm{Cr}(\mathrm{VI})$, including conversion ratio, conversion rate and redox equilibration time varied with the constituents of the photochemical system that was made up of same transition metals and different species of marine phytoplankton or same species of marine phytoplankton and different transition metals. The difference of the combined effect of marine phytoplankton and transition metals on the reduction of $\mathrm{Cr}(\mathrm{VI})$ was due to two reasons: (a) if the species of marine phytoplankton is different, the influence factors of marine phytoplankton on the photochemical reduction of $\mathrm{Cr}(\mathrm{VI})$ as mentioned above were all different; and (b) if the transition metal is different; the complexing reaction with marine phytoplankton is different, too.

Chromium(VI) could be reduced to $\mathrm{Cr}(\mathrm{III})$ by the marine phytoplankton-light, transition metals-light, and marine phytoplankton-transition metals-light systems. The photochemical activity for the reduction of $\mathrm{Cr}(\mathrm{VI})$ was analyzed and compared in Table 2. The photochemical behaviors of marine phytoplankton-transition metals-light systems $\left(\mathrm{S}_{3}\right)$ on the conversion ratio of $\mathrm{Cr}(\mathrm{VI})$ were the combination effects from the photoreduction activity of marine phytoplankton $\left(\mathrm{S}_{1}\right)$, as the main contributor, and the photoreduction activity of transition metals $\left(\mathrm{S}_{2}\right)$.

The photoreduction activity of the marine phytoplankton-transition metals-light system was higher than that in the transition metals-light system, i.e., the value of $\left(\mathrm{S}_{3}-\mathrm{S}_{2}\right)$ in Table 2 , for three reasons: (a) marine phytoplankton on its own has photoreduction activity, especially for photo-production of hydrated electrons and releasing of the electron donors; (b) marine phytoplankton could adsorb, concentrate and coordinate transition 
metals and chromium and thus change the redox potentials of transition metals and chromium; and (c) the content of the potential $\mathrm{Cr}(\mathrm{VI})$ reductants, including $\mathrm{Fe}(\mathrm{II})_{2} \mathrm{Cu}(\mathrm{I}), \mathrm{Mn}(\mathrm{II})$ and $\mathrm{O}_{2}{ }^{-}$by transition metals might be enhanced by their organic ligands. For example, organic Fe(III) complexes $\left(\mathrm{Fe}^{3+}\right.$-org) are the main species of Fe(III) in the solution of $\mathrm{Fe}^{3+}$ with algae (Zuo and Hoigné, 1992; Zuo and Hoigné, 1993; Zuo and Jones, 1997; Liu et al., 2004). The effects of $\mathrm{Fe}^{3+}$ are described below.

$$
\mathrm{Fe}^{3+}-\mathrm{org}+h v \rightarrow \mathrm{Fe}^{2+}+\text { org radical }
$$$$
\text { org radical }+\mathrm{O}_{2} \rightarrow \mathrm{O}_{2}^{-} \cdot+\text { oxidized org }
$$

The presence of transition metals increases the $\mathrm{Cr}(\mathrm{VI})$ reduction for 3 of the algae (A, $\mathrm{C}$ and $\mathrm{G}$ ), has no impact for the algae $\mathrm{B}$, but inhibits the reduction for 3 of the alga (D, E and F), according to the values of $\left(\mathrm{S}_{3}-\mathrm{S}_{1}\right)$ in Table 2. The species and concentration of $\mathrm{Cr}(\mathrm{VI})$ on the surface of algae or transition metal complexes might be affected by the coexistence of the alga and transition metal. A different mechanism is probably responsible for the $\mathrm{Cr}(\mathrm{VI})$ reduction by absorbing surfaces such as alga, transition metal complexes.

In marine phytoplankton-transition metals-light systems which are very close to the sunlit surface seawater, $\mathrm{Cr}(\mathrm{VI})$ was transformed into $\mathrm{Cr}$ (III) by photo-reduction. The ratio of $\mathrm{Cr}(\mathrm{VI})$ to $\mathrm{Cr}(\mathrm{III})$ was 0.48 for Phaeodactylum tricornutum (diatom), 0.71 for Porphyridium purpureum (red alga), and ranged from 1.45 to 2.16 for five green algae(Tetraselmis levis, Chlorella autotrophica, Dunaliella salina, Nannochloropsis sp. and Tetraselmis subcordiformis). The most effective at reducing $\mathrm{Cr}$ (VI) was a diatom that are known to produce high concentrations of organic matter in the form of transparent exopolymer particles (Passow et al. 1994),

dissolved organic matter mediated control of $\mathrm{Cr}$ reduction might be possible. The results were listed in Table 3 , providing explanation for the distribution of $\mathrm{Cr}(\mathrm{VI})$ and $\mathrm{Cr}(\mathrm{III})$, obtaining useful information to understand the biogeochemical cycle of chromium. This study is beneficial to deal with assessment of the risk/bioavailability of $\mathrm{Cr}(\mathrm{VI}) / \mathrm{Cr}(\mathrm{III})$ in sunlit surface seawater.

\section{Summary}


323

324

325

326

327

328

329

330

331

The influence of marine phytoplankton itself (excluding its exudates such as DOM) on the photo-reduction of trace metals was confirmed for the first time. The conversion ratio of $\mathrm{Cr}(\mathrm{VI})$ to $\mathrm{Cr}(\mathrm{III})$ increased with increasing algae concentration and irradiation time. Different species of marine phytoplankton were found to have different photo-reducing abilities. In addition to the photo-production of hydrated electrons, marine phytoplankton could adsorb, concentrate and coordinate transition metals and chromium, change their redox potentials, and affected their photochemical activities. The effect of the marine phytoplankton-transition metal-light system on the chromium species transformation, especially the addition of marine phytoplankton, was most important. We tried to interpret the observed relationships between $\mathrm{Cr}$ (VI) and Cr(III), and provided further information for the understanding of the biogeochemical cycle of chronium, as well as for the risk assessment of chromium in the sunlit surface seawater.

\section{Acknowledgements}

This research was supported by grants from National natural Science Foundation of China (No. 40506020) and Science \& Technology Committee of Fujian Province, China (No. K02093 and No.2003J035). Authors gratefully acknowledge the reviewers of this article.

\section{References}

Abu-Saba K.E., David L.S., Flegal A.R. 2000. Indirect reduction of hexavalent chromium by copper in the presence of superoxide. Mar. Chem. 69:33-41.

Buerge I.J., Hug S.J. 1997. Kinetics and pH dependence of chromium(VI) reduction by iron(II). Environ. Sci. Technol. 31:1426-1432.

Calza P., Pelizzetti E.2004. Reactivity of chloromethanes with photogenerated hydrated electrons. J. Photoche. Photobio. A 162:609-613.

Cieśla P., Karocki A., Stasicka Z. 2004. Photoredox behaviour of the Cr-EDTA complex and its environmental 
aspects. J. Photoche. Photobio. A 162:537-544.

Cieśla P., Mytych P., Kocot P., Stasicka Z. 2007. Role of iron and chromium complexes in environmental self-cleaning processes. Sep. Sci. Technol. 42:1651-1666.

Connelly D.P., Statham P.J., Knap A.H. 2006. Seasonal changes in speciation of dissolved chromium in the surface Sargasso Sea. Deep-Sea Res. I, 53:1975-1988.

Costa M., Liss P. 2000. Photoreduction and evolution of mercury from seawater. Sci. Total Environ. 261:125135.

Deng N.S., Wu F., Tian S.Z. 1997. Progress in research on formations and photochemical reactions of hydrogen peroxide in natural waters. Chin. J. Advance in Environ. Sci. 5:1-9.

Deng Y.W., Chen H., Wu T.X., Krzyaniak M., Wellons A., Bolla D., Douglas K., Zuo Y.G. 2006. Iron-catalyzed photochemical transformation of benzoic acid in atmospheric liquids: Product identification and reaction mechanisms. Atmos. Environ. 40:3665-3676.

Elderfield H. 1970. Chromium speciation in sea water. Earth Planet Sci. lett. 9:10-16.

Feng S.Z., Li F.Q. Li S.Q. 1999. Marine Science. Chinese Beijing:High Education Press. p335.

Gaberell M., Chin Y.P., Hug S. J., Sulzberger B. 2003. Role of dissolved organic matter composition on the photoreduction of Cr(VI) to Cr(III) in the presence of iron. Environ. Sci. Technol. 37:4403-4409.

Gardan-Torresday J.L., Becker-Hapak M.K., Darmell D.W. 1990. Effect of chemical, modification of algal carboxyl groups on metal ion binding.Environ. Sci. Technol. 24(9):1372-1378.

Hirata S., Honda K., Shikino O., Maekawa A.M. 2000. Determination of chromium(III) and total chromium in seawater by on-line column preconcentration inductively coupled plasma mass spectrometry. Spectrochim. Acta Part B 55:1089-1099.

Hug S.J., Laubscher H.U., James B.R. 1997. Iron(III) catalyzed photochemical reduction of Chromium(VI) by oxalate and citrate in aqueous solutions. Environ. Sci. Technol. 31:160-170. 
Kieber R.J., Helz G.R. 1992. Indirect photoreduction of aqueous chromium(VI). Environ. Sci. Technol.

$$
\text { 26:307-12. }
$$

Kocot P., Szaciłowski K., Stasicka Z. 2007. Photochemistry of the [FeIII(edta)(H2O)]- and [FeIII(edta)(OH)]2complexes in presence of environmentally relevant species. J. Photoche. Photobio. A 188:128-134.

Li S.X., Zheng F.Y., Hong H.S., Deng N.S., Zhou X.Y. 2006a. Photo-oxidation of Sb(III) in the seawater by marine phytoplankton-transition metals-light system. Chemosphere 65:1432-1439.

Li S.X., Zheng F.Y., Hong H.S., Huang B.Q., Wang D.Z., Lin H.Q., Lin L. 2006b. Effects of nitrate and phosphate on the biochemical composition of marine phytoplankton. Chinese J. Mar. Sci. 30(1):49-53.

Li S.X., Hong H.S., Zheng F.Y., Deng N.S., Lin F. 2007. Influence of nitrate on metal sorption and bioaccumulation in marine phytoplankton, Dunaliella salina. Environ. Toxicol. 22:582-586.

Li S.X., Zheng F.Y., Hong H.S., Huang G.Z. 2008. Effects of macronutrients, lead and mercury on the photoproduction of hydroxyl radicals in seawater with marine algae ,Dunaliella salina. Mar. Chem. 108:207-214.

Liu X.L., Wu F., Deng N.S. 2004. Photoproduction of hydroxyl radicals in aqueous solution with algae under high-pressure mercury lamp. Environ. Sci. Technol. 38:296-299.

Mertz W. 1993. Chromium in human nutrition-a review. J. Nutr. 123:626-633.

Millero F.J. 1989. Effect of ionic interactions of the oxidation of $\mathrm{Fe}(\mathrm{II})$ and $\mathrm{Cu}(\mathrm{I})$ in natural waters. Mar. Chem.

$$
28: 1-18
$$

Mytych P., Karocki A., Stasicka Z. 2003. Mechanism of photochemical reduction of chromium(VI) by alcohols and its environmental aspects. J. Photoche. Photobio. A 160: 163-170.

Mytych P., Stasicka Z. 2004. Photochemical reduction of chromium(VI) by phenol and its halogen derivatives. Appl. Catal. B-Environ. 52:167-172.

Nicolai M., Rosin C., Tousset N., Nicolai Y. 1999. Trace metals analysis in estuarine and seawater by ICP-MS 

using on line preconcentration and matrix elimination with chelating resin. Talanta 50:433-444.

Passow U., Alldredge A., Logan B., 1994. The role of particulate carbohydrate exudates in the flocculation of diatom blooms. Deep-Sea Res. I, 41:335-357.

Petasne R.G., Zika R.G. 1987. Fate of superoxide in coastal seawater. Nature 325:516-518.

Pettine M., Millero F.J. 1990. Chromium speciation in seawater: the probable role of hydrogen peroxide. Limnol. Oceanogr. 35:730-736.

Pettine M., Millero F.J., La N.T. 1991. Chromium(III) interaction in seawater through its oxidation kinetics. Mar. Chem. 34: 29-46.

Pettine M., Millero F.J., Passino R. 1994. Reduction of chromium(VI) with hydrogen sulfide in $\mathrm{NaCl}$ media. Mar. Chem. 46:335-344.

Powell R.T., Wilson-Finelli A. 2003. Photochemical degradation of organic iron complexing ligands in Seawater. Aquat. Sci. 65:367-374.

Richard F.C., Bourg ACM. 1991. Aqueous geochemistry of chromium-a review. Water Res. 25:807-816.

Roitz J.S., Flegal A.R., Bruland K.W. 2002. The biogeochemical cycling of manganese in San Francisco Bay: temporal and spatial variations in surface water concentrations. Estuarine Coastal Shelf Sci. 54:227-239.

Rose A.L., Waite T.D. 2003. Predicting iron speciation in coastal waters from the kinetics of sunlight-mediated iron redox cycling. Aquat. Sci. 65:375-383.

Sanders J.G., Riedel G.F. 1987. Control of trace element reactivity by phytoplankton, p.131-149 in J.A. Saunders, L. Kosak-Channing and EE Conn, Phytochemical effects of environmental compounds, Plenum Publishing Co.

Schmitt D., Muller A., Csogor Z., Frimmel F.H., Posten C. 2001. The adsorption kinetics of metal ions onto different microphytoplankton and siliceous earth. Water Res. 35:779-785.

Smillie R.H., Hunter K., Loutit M. 1981. Reduction of chromium(VI) by bacterially produced hydrogen 
414

415

416

417

418 sulphide in a marine environment. Water Res. 15:1351-1354.

Standeven A.M., Wetterhahn K.E. 1991. Is there a role for reactive oxygen species in the mechanism of chromium(VI) carcinogenesis? Chem. Res. Toxicol. 4:616-625.

Sulzberger B., Canonica S., Egli T., Giger W., Klausen J., Gunten U. 1997. Oxidative transformations of contaminants in natural and in technical systems. Chimia 51:900-907.

Tengku-Rozaina T.M., Ibrahim S. 2001. Phytoplankton in the East Coast of Peninsular Malaysia In: Mohd-Taupek MN and Mansor MI (eds.). Fisheries Resources Survey in the Exclusive Economic Zone of Malaysia 1997-1999: Biology and Environmental Conditions (Supplementary Volume), Department of Fisheries, Ministry of Agriculture Malaysia; p72-79

Thomas-Smith T.E., Blough N.V. 2001. Photoproduction of hydrated electron from constituents of natural waters. Environ. Sci. Technol. 35:2721-2726.

Tovar-Sanchez A., Sanudo-Wilhelmy S.A., Garcia-Vargas M., Weaver R.S., Popels L.C., Hutchins D.A. 2003. A trace metal clean reagent to remove surface-bound iron from marine phytoplankton. Mar. Chem. 82:91-99.

U.S.EPA. 2006. http://www.epa.gov/safewater/dwh/t-ioc/chromium.html. August 16th.

Voelker B.M., Sedlak D.L. 1995. Iron reduction by photoproduced superoxide in seawater. Mar. Chem. 50:93-102.

Voelker B.M., Sedlak D.L., Zafiriou OC. 2000. Chemistry of superoxide radical in seawater; reactions with organic Cu complexes. Environ. Sci. Technol. 34:1036-1042.

Wang X., Ma Y., Su Y. 1997. Determining Surface Areas of Marine Alga Cell by Acid-base titration method. Chemosphere 35(5):1131-1141.

Wang Y., Yang G. 2004. Photochemical reaction of inorganic matters in seawater. Chin. J. Mar. Sci. 23:73-81.

White E.M., Vaughan P.P., Zepp R.G. 2003. Role of the photo-Fenton reaction in the production of hydroxyl radicals and photobleaching of colored dissolved organic matter in a coastal river on the southeastern 
Wu F., Zhang L., Deng N.S., Zuo Y.G. 2004. Quantitation for photoinduced formation of hydroxyl radicals in the water-containing Fe(III) and oxalate salts. Fresen. Environ. Bull. 13:748-752.

Yang Y.P., Hu M.H., Wang P.X. 1994. Speciation transformation of chromium in seawater by bacteria. Acta Ocennologic. Sinica 16:72-79.

Zafiriou O.C. 1990. Chemistry of superoxide ion-radical $\left(\mathrm{O}_{2}^{-}\right)$in seawater. I. $p \mathrm{~K}_{\text {asw }}^{*}(\mathrm{HOO})$ and uncatalyzed dismutation kinetics studied by pulse radiolysis. Mar. Chem. 30:31-43.

Zepp R.G., Schlotzhauer P.F. 1983. Influence of phytoplankton on photolysis rates of chemicals in water. Environ. Sci. Technol. 17:462-468.

Zhang G., Yi Z., Wallace G.T. 1995. Iron(II) in rainwater, snow, and surface seawater from a coastal environment. Mar. Chem. 50:41-50.

Zhang H. 2000. light and Iron(III)-induced oxidation of chromium(III) in the presence of organic acids and manganese(II) in simulated atmospheric water. Atmos. Environ. 34:1633-1640.

Zhang L., Yang G.P. 2000. Studies on marine photochemistry of Fe, Mn, and Cu: A review. Chin. J. Mar. Sci. 10:33-36.

Zhang Z., Wu F., Deng N.S. 2001. Photochemical reduction of $\mathrm{Cr}(\mathrm{VI})$ in aqueous solutions containing Fe(III)-hydroxy complexes. Toxicolog. Environ. Chem. 82:129-137.

Zhu G.H., Li S.X. 2001. Separation and preconcentration of chromium species by selective absorption on lemna. Minor. and determination by slurry atomization electrothermal atomic absorption spectrometry. Analyst 126:1453-1455.

Zuo Y., Hoigné J. 1992. Formation of hydrogen peroxide and depletion of oxalic acid in atmospheric water by photolysis of iron(III)-oxalato complexes. Environ. Sci. Technol. 26:1014-1022. 
459

460

461

462

Zuo Y., Hoigné J. 1993. Evidence for photochemical formation of $\mathrm{H}_{2} \mathrm{O}_{2}$ and oxidation of $\mathrm{SO}_{2}$ in authentic fog water. Science 260:71-73.

Zuo Y., Jones R. 1997. Photochemistry of natural dissolved organic matter in lake and wetland watersproduction of carbon monoxide. Water Res. 31:850-858. 
Table 1

Photoreduction of $\mathrm{Cr}(\mathrm{VI})$ by transition metals

\begin{tabular}{|c|c|c|c|c|c|c|c|}
\hline Transition metals & $\mathrm{Fe}(\mathrm{III})$ & $\mathrm{Cu}(\mathrm{II})$ & $\mathrm{Mn}(\mathrm{II})$ & $\mathrm{Fe}(\mathrm{III})+\mathrm{Cu}(\mathrm{II})$ & $\mathrm{Fe}(\mathrm{III})+\mathrm{Mn}(\mathrm{II})$ & $\mathrm{Cu}(\mathrm{II})+\mathrm{Mn}(\mathrm{II})$ & $\mathrm{Fe}(\mathrm{III})+\mathrm{Cu}(\mathrm{II})+\mathrm{Mn}(\mathrm{II})$ \\
\hline Conversion percent (\%) & 8.1 & 10.8 & 6.8 & 12.5 & 10.0 & 11.2 & 13.3 \\
\hline Redox equilibration time (hour) & $3 \mathrm{~h}$ & $5 \mathrm{~h}$ & $6 \mathrm{~h}$ & $5 \mathrm{~h}$ & $6 \mathrm{~h}$ & $6 \mathrm{~h}$ & $6 \mathrm{~h}$ \\
\hline
\end{tabular}

Table 2

Photoreduction of $\mathrm{Cr}$ (VI) by marine phytoplankton, transition metals, marine phytoplankton and transition metals

\begin{tabular}{|c|c|c|c|c|c|c|c|}
\hline Photoreduction System & \multicolumn{7}{|c|}{ Conversion percent $(\%)$} \\
\hline & $\begin{array}{c}\text { Phaeodactylum } \\
\text { tricornutum }\end{array}$ & $\begin{array}{l}\text { Porphyridium } \\
\text { purpureum }\end{array}$ & $\begin{array}{l}\text { Tetraselmis } \\
\text { levi }\end{array}$ & $\begin{array}{c}\text { Chlorella } \\
\text { autotrophic }\end{array}$ & $\begin{array}{l}\text { Dunaliella } \\
\text { salina }\end{array}$ & $\begin{array}{l}\text { Nannochloro } \\
\text { psis sp. }\end{array}$ & $\begin{array}{c}\text { Tetraselmis } \\
\text { subcordiformis }\end{array}$ \\
\hline Alga and $\mathrm{Cr}(\mathrm{VI})\left(\mathrm{S}_{1}\right)$ & 46.9 & 56.7 & $32.9-$ & 47.1 & 52.9 & 44.3 & 26.4 \\
\hline $\mathrm{Fe}(\mathrm{III}), \mathrm{Cu}(\mathrm{II}), \mathrm{Mn}(\mathrm{II})$ and $\mathrm{Cr}(\mathrm{VI})\left(\mathrm{S}_{2}\right)$ & & & & 13.3 & & & \\
\hline Alga, $\mathrm{Fe}(\mathrm{III}), \mathrm{Cu}(\mathrm{II}), \mathrm{Mn}(\mathrm{II})$ and $\mathrm{Cr}(\mathrm{VI})\left(\mathrm{S}_{3}\right)$ & 67.6 & 58.7 & 40.9 & 31.7 & 35.1 & 33.3 & 32.4 \\
\hline $\mathrm{S}_{3}-\mathrm{S}_{1}$ & 20.7 & 2.0 & 8.0 & -15.4 & -17.8 & -11.0 & 6.0 \\
\hline $\mathrm{S}_{3}-\mathrm{S}_{2}$ & 54.3 & 45.4 & 27.6 & 18.4 & 21.8 & 20.0 & 19.1 \\
\hline
\end{tabular}

The content of marine phytoplankton was $10 \mathrm{ng} / \mathrm{mL}$. The concentration of Fe(III), Cu(II) and Mn(II) was 55, 250 and 14 ng/L, respectively.

Table 3

Ratio of $\mathrm{Cr}(\mathrm{VI})$ to $\mathrm{Cr}(\quad$ ) after photoreduction by marine phytoplankton-transition metals-light system

\begin{tabular}{|c|c|c|c|c|c|c|c|}
\hline Alga & $\begin{array}{c}\text { Phaeodactylum } \\
\text { tricornutum }\end{array}$ & $\begin{array}{l}\text { Porphyridium } \\
\text { purpureum }\end{array}$ & Tetraselmis levi & $\begin{array}{c}\text { Chlorella } \\
\text { autotrophic }\end{array}$ & Dunaliella salina & $\begin{array}{c}\text { Nannochloropsis } \\
\text { sp. }\end{array}$ & $\begin{array}{c}\text { Tetraselmis } \\
\text { subcordiformis }\end{array}$ \\
\hline Ratio of $\mathrm{Cr}(\mathrm{VI})$ to $\mathrm{Cr}(\mathrm{III})$ & 0.5 & 0.7 & 1.4 & 2.2 & 1.8 & 2.0 & 2.1 \\
\hline
\end{tabular}

The content of marine phytoplankton was $10 \mathrm{ng} / \mathrm{mL}$. The concentration of Fe(III), Cu(II) and Mn(II) was 55, 250 and 14 ng/L, respectively. 


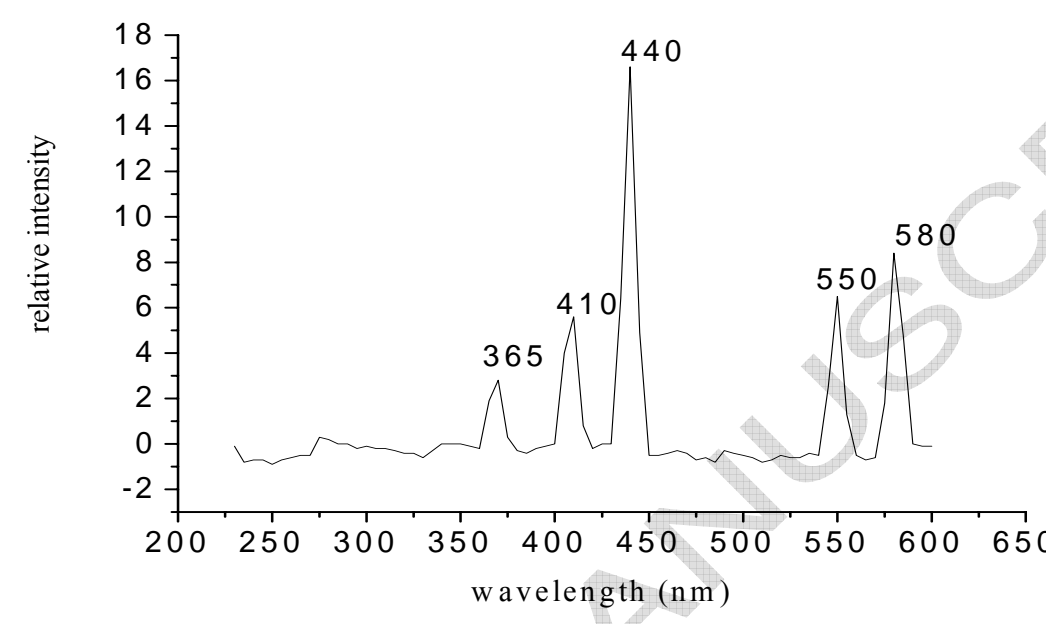

Fig. 1. Emission spectrum of the high-pressure mercury lamp 


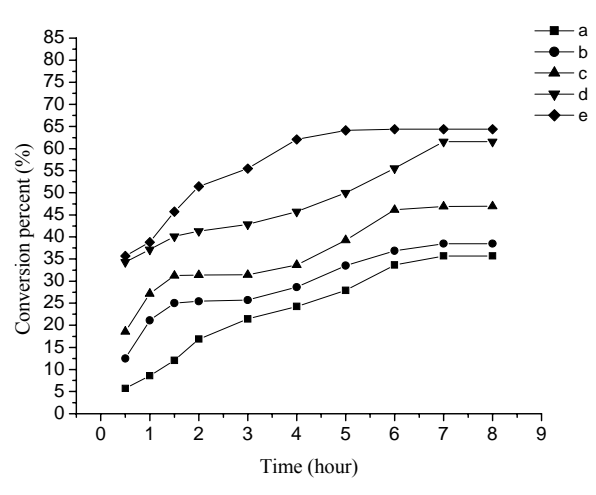

Phaeodactylum tricornutum

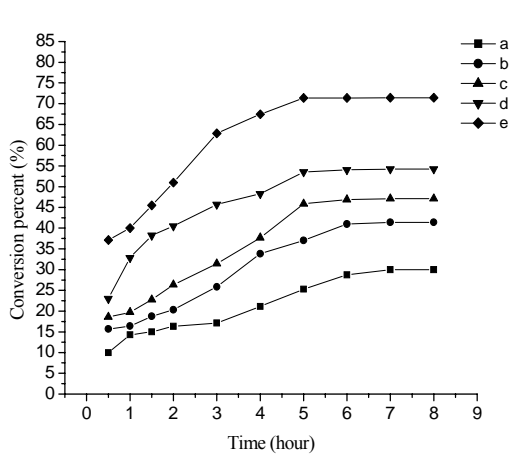

Chlorella autotrophic

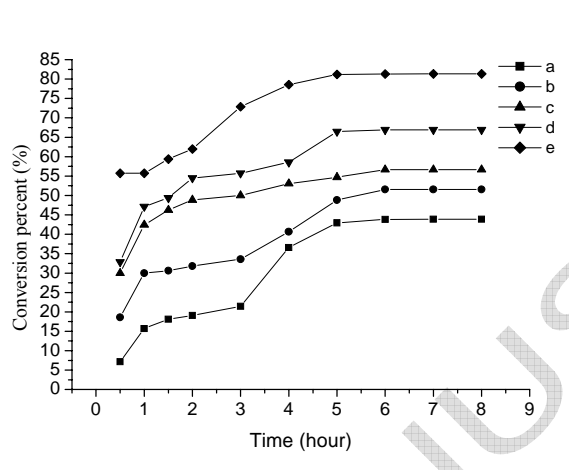

Porphyridium purpureum

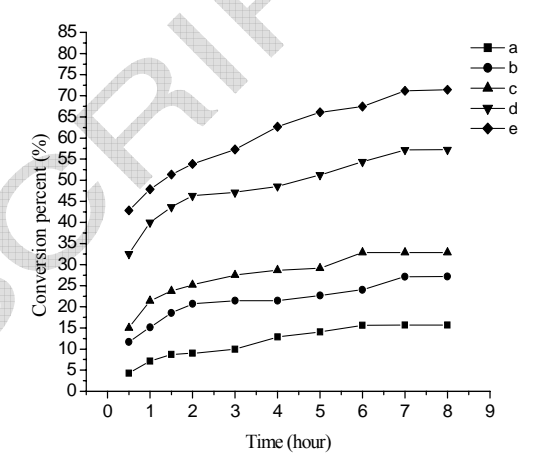

Tetraselmis levi

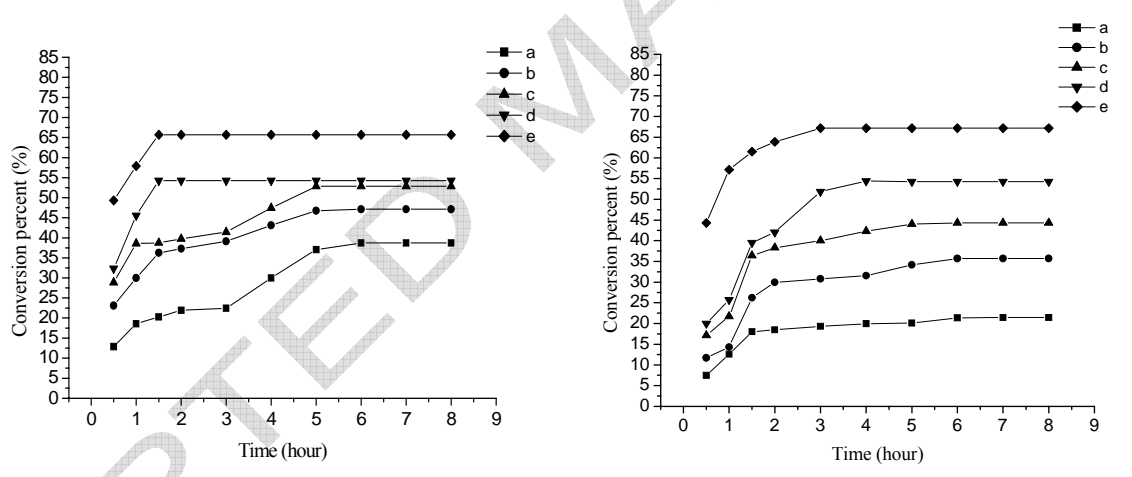

Nannochloropsis sp.

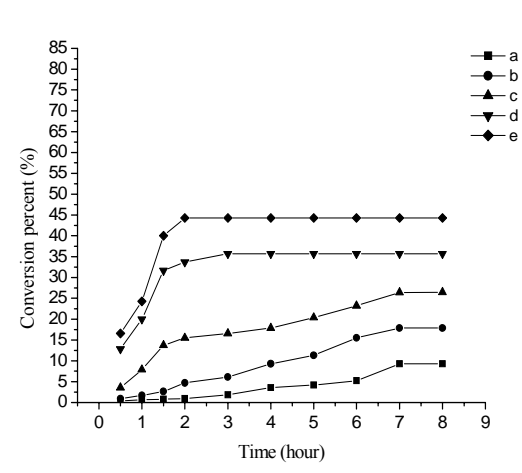

Tetraselmis subcordiformis

Fig. 2. Photoreduction of $5 \mu \mathrm{g} \mathrm{L}^{-1} \mathrm{Cr}(\mathrm{VI})$ in the presence of marine phytoplankton at concentrations of a) 5 , b) 8 , c) 10 , d) 15 and e) $20 \mathrm{ng} \mathrm{ml}^{-1}$ 


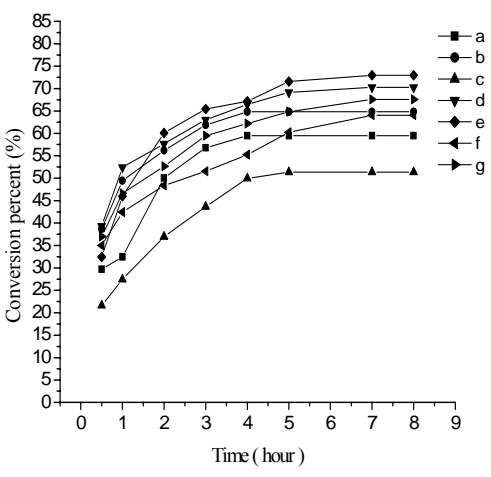

Phaeodactylum tricornutum

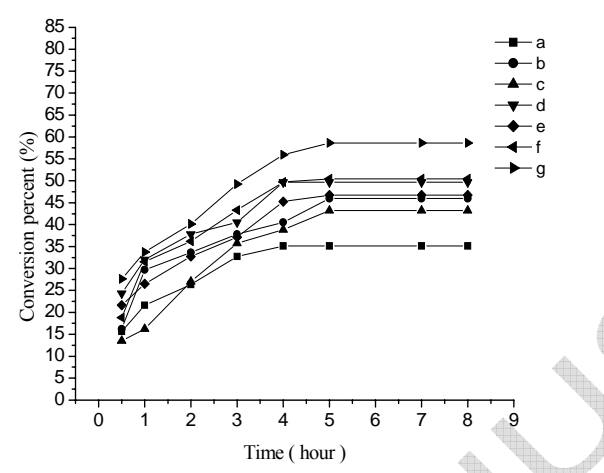

Porphyridium purpureum

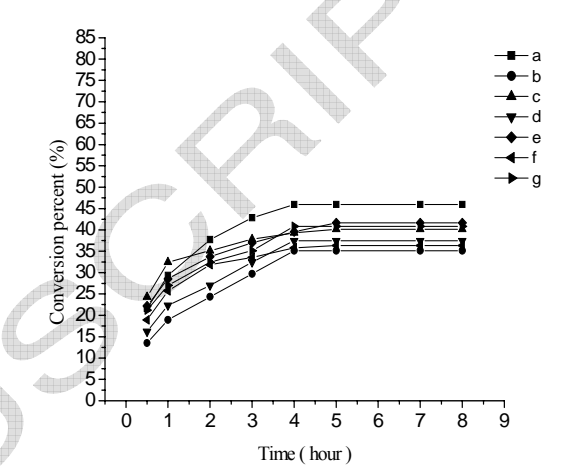

Tetraselmis levi

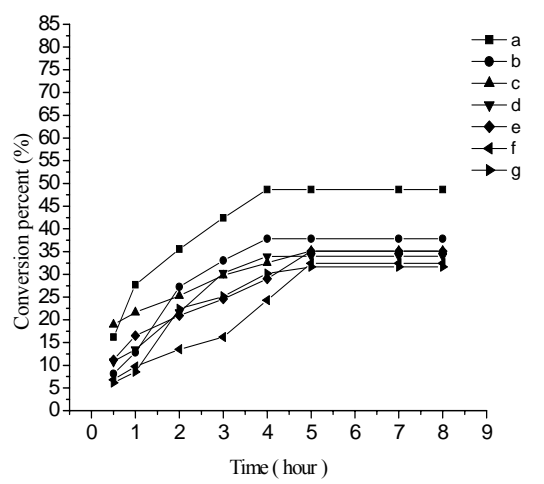

Chlorella autotrophic

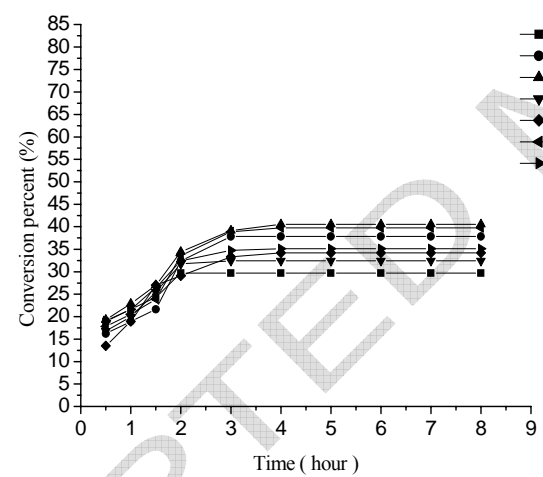

Dunaliella salina

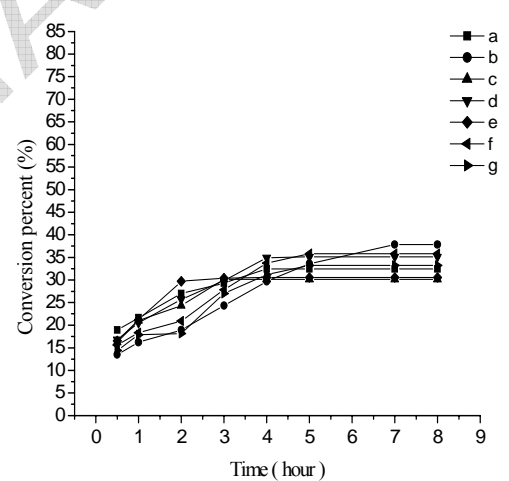

Nannochloropsis sp.

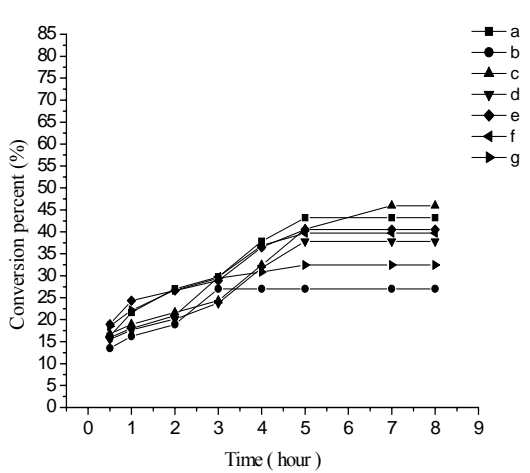

Tetraselmis subcordiformis

Fig. 3. Photoreduction of $\mathrm{Cr}(\mathrm{VI})\left(5 \mu \mathrm{g} \mathrm{L}^{-1}\right)$ in the presence of marine phytoplankton and transition metals. The content of marine phytoplankton was $10 \mathrm{ng} \mathrm{ml}^{-1}$. The concentration of $\mathrm{Fe}(\mathrm{III}), \mathrm{Cu}(\mathrm{II})$ and $\mathrm{Mn}(\mathrm{II})$ is 55,250 and $14 \mathrm{ng} \mathrm{L}^{-1}$, respectively. a: $\mathrm{Fe}(\mathrm{III}) \quad$ b: $\mathrm{Cu}(\mathrm{II}) \quad$ c: $\mathrm{Mn}(\mathrm{II}) \quad \mathrm{d}$ : $\mathrm{Fe}(\mathrm{III})$ and $\mathrm{Cu}(\mathrm{II}) \quad$ e: $\mathrm{Fe}(\mathrm{III})$ and $\mathrm{Mn}$ (II) $\quad$ f: $\mathrm{Cu}(\mathrm{II})$ and $\mathrm{Mn}$ (II) g: $\mathrm{Fe}(\mathrm{III}), \mathrm{Cu}(\mathrm{II})$ and $\mathrm{Mn}$ (II) 